\title{
ERRATUM
}

\section{EPISTEMIC INJUSTICE IN THE SPACE OF REASONS - ERRATUM}

\section{MATTHEW CONGDON}

doi:Io.ror 7 /epi.20I4.34. Published online by Cambridge University Press 2 February 2015.

In the above mentioned article by Congdon (2015), an error has been noted at the beginning of the $4^{\text {th }}$ paragraph in section 3 . The following sentence:

Why isn't the space of reasons not like this?

Should read:

Why isn't the space of reasons like this?

\section{REFERENCE}

Congdon, M. 201 5. 'Epistemic Injustice in the Space of Reasons.' Episteme, I 2: 75-93. doi:IO.IOI7/epi.20I4.34. 